\title{
Modeling of physical dispersion using script environment in Petrel
}

This paper concerns a practical solution of the problem resulted from the modeling of physical dispersion phenomenon occurring during fluid mixing in porous media. This is a continuation of the author's previous works, in which calculations have been performed with the use of a modified "open code" reservoir simulator (BOAST). As a part of the previous work, the developed method of controlling the fluids mixing has been implemented directly in the simulator code, while the current paper includes the implementation of this method in the Petrel script environment allowing direct access to simulation results performed on the standard Eclipse reservoir simulator. The paper contains a brief description of the script environment applied, a short description of the method of controlling the numerical dispersion and a description of the structure of the constructed script. The method of controlling the physical dispersion proposed in the paper is based on iterative calling of a standard reservoir simulator, exporting the obtained simulation results and performing calculations using to modify the obtained reservoir fluids saturation. Calculated saturations in a given step of the script iteration constitute the input data to the next step performed in the script. The proposed method was tested on a simplified one-dimensional simulation model, which assumed constant petrophysical parameters and stationary pressures. The results of the developed script are presented in the form of drawings showing various values of smearing of the zone of mixing of two reservoir fluids (water and crude oil). These results showed the effectiveness of the applied method of minimization of the numerical dispersion (through grid refinement and calculation of fluid mobility through multipoint upstream weighting in the direction of inflow) and the effects of using explicit parameters to control the physical dispersion.

Key words: reservoir simulations, numerical dispersion, physical dispersion, mixing of fluids.

\section{Modelowanie zjawiska dyspersji fizycznej z wykorzystaniem środowiska skryptowego programu Petrel}

Artykuł ten dotyczy praktycznego rozwiązania problemu związanego z modelowaniem zjawiska dyspersji fizycznej zachodzącego podczas mieszania się płynów w ośrodkach porowatych. Jest to kontynuacja poprzednich prac autora, w których obliczenia wykonano przy użyciu zmodyfikowanego symulatora złożowego typu „open code” (BOAST). W ramach prac poprzednich opracowaną metodę sterowania zjawiskiem mieszania się płynów zaimplementowano bezpośrednio w kodzie symulatora, natomiast obecny artykuł dotyczy implementacji tej metody w środowisku skryptowym programu Petrel umożliwiającym bezpośredni dostęp do wyników symulacji wykonanych na standardowym symulatorze złożowym Eclipse firmy Schlumberger. Artykuł zawiera krótki opis zastosowanego środowiska skryptowego, krótki opis metody sterowania dyspersją numeryczną oraz opis budowy skonstruowanego skryptu. Zaproponowana w ramach artykułu metoda sterowania zjawiskiem dyspersji fizycznej polega na iteracyjnym wywoływaniu standardowego symulatora złożowego, eksporcie uzyskanych wyników symulacji i wykonaniu na nich obliczeń modyfikujących uzyskane nasycenia płynami złożowymi. Wyliczone nasycenia płynami w danym kroku iteracji skryptu stanowią dane wejściowe do następnego kroku wykonywanego w skrypcie. Zaproponowaną metodę przetestowano na uproszczonym jednowymiarowym modelu symulacyjnym, w którym założono stałe parametry petrofizyczne oraz ciśnienia stacjonarne. Wyniki zastosowania opracowanego skryptu pokazano w postaci rysunków przedstawiających różne wielkości rozmycia strefy mieszania się dwóch płynów złożowych (wody i ropy). Rezultaty te wykazały efektywność stosowanej metody minimalizacji dyspersji numerycznej (poprzez zagęszczenie siatki oraz obliczanie mobilności płynów poprzez wielopunktowe ważenie w kierunku napływu) oraz efekty zastosowania różnych wielkości parametrów sterujących dyspersją fizyczną.

Słowa kluczowe: symulacje złożowe, dyspersja numeryczna, dyspersja fizyczna, mieszanie się płynów. 


\section{Introduction}

Where injecting fluids into hydrocarbon reservoirs, the phenomenon of physical dispersion $[3,19]$ occurs when the injected fluid is mixed with the original fluid present in the formation. This phenomenon is very important in the underground gas storage practices $[2,9,10,13,24,25]$ (especially during the production of non-hydrocarbon buffer cushion or injection of high-methane natural gas into formations containing heavily polluted original gas) and in situations where attempts are made to increase the energy of the oil-gas reservoir by injecting gas into its gas cap. Although physical dispersion has a significant influence on the process of fluid mixing in hydrocarbon formations, it has not been correctly included in available reservoir simulators (both open code and commercial ones).

This paper is a continuation of the previous works of the author $[11,12,14,17,26]$ within the framework of which a reservoir simulator was built (through modification of the BOAST reservoir simulator [7]) correctly taking into account the phenomenon of fluid mixing. Modifications of the simulator concerned implementation of the hybrid method of minimizing numerical dispersion (mobility with multi-point upstream weighting [27] and double discretization grid [1]) and extension of standard saturation equations with additional terms of physical dispersion with control parameters $[15,18,20$, $22,23]$. These changes were tested on both simplified simulation models (in which fixed size of blocks, homogeneous reservoir parameters and stationary flow of reservoir fluids were assumed) and the actual formation model (selected natural gas reservoir model).

As a part of this work, an attempt was made to model the phenomenon of reservoir fluid mixing with the use of a commercial reservoir simulator: Eclipse by Schlumberger [5]. In addition to the reservoir simulator, a scripting environment (Workflow) provided by Schlumberger in Petrel program was used to perform the work.

\section{Physical dispersion control method}

The method of controlling of the mixing of two reservoir fluids proposed under the discussed work is a different approach to solving this problem in comparison with previous works of the authors. The previous works have modified the source code of the BOAST simulator, in which the physical dispersion control method described below has been implemented. The proposed method consists of two steps:

- minimization of numerical dispersion (smearing of simulation results obtained from the calculation method applied - discretization of derivatives by finite differences plus upstream weighting of mobility calculations assuring stability of numerical solutions),

- extension of the equations by physical dispersion terms under this paper, it was decided to create an external software (in the form of a script) enabling the control of mixing of reservoir fluids based on the results obtained with the use of Eclipse simulator. For this purpose, a scripting environment provided in Petrel program was used, allowing direct access to the simulation results obtained.

\section{The script environment of Petrel program}

The script environment made available in Petrel program provides users with many possibilities. Almost all operations that a user can perform interactively in Petrel can be automated by creating the so-called Workflow, in which most of the tools and processes of this software are made available (Figure 1).

(adding to the simulator the parameters enabling the control of physical dispersion by setting a dispersion coefficients: constant or linearly dependent on flow velocity).

Within the frameworks of the discussed work, an attempt was made to use this method to model physical dispersion with the use of a commercial reservoir simulator - Eclipse. Although the previous solution is correct, the open code reservoir simulators (such as BOAST) are not used in the practice of commercial projects.

Since the owners of commercial reservoir simulators do not make their source code available, it is impossible to implement the proposed method in case of these simulators. Therefore,

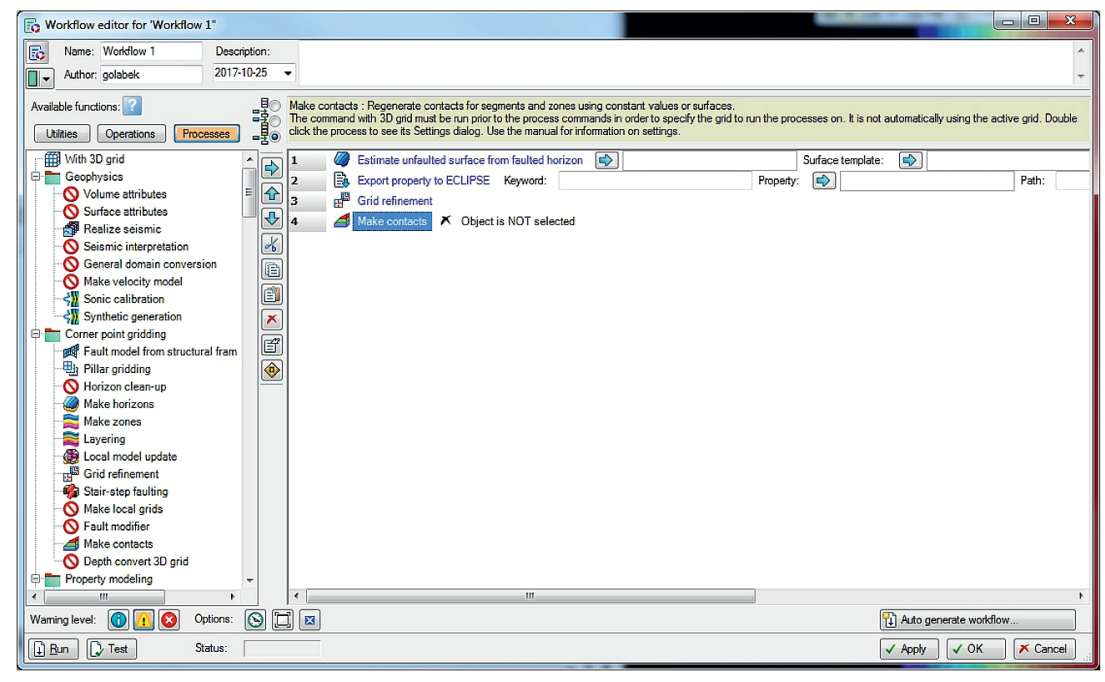

Fig. 1. Petrel script environment - exemplary Workflow 
The available options allow for automation of both static and dynamic modeling, allow automatic import and export of data, creation and modification of the existing parameters distribution or construction of the simulation case. The main advantage of this environment is the availability of calculators (Property calculator or Map calculator) which allow to make complicated calculations on grids (with up to several million nodes) easy. In addition to the use of the typical tools of Petrel program, the scripting environment allows the addition of fixed, variable values, conditional instructions and recursive loops. Thanks to these options, one can, for example, perform multiple field simulations with different input data, or generate multiple distributions of petrophysical parameters using different variograms.

\section{Construction of physical dispersion control script}

Since the physical dispersion control method developed in previous works is technically quite complicated, this paper presents a solution for one dimension models. Solutions for two and three dimension models will be developed in the author's planned work.

First of all, a static one-dimensional model (consisting of 4 blocks in the $\mathrm{Y}$ direction with the sizes of $100 \times 100 \times 100 \mathrm{~m}$ ) was created in Petrel program, for which fixed reservoir parameters were assumed (permeability $=100 \mathrm{mD}$, porosity $=0.2$, NTG = 1). Subsequently, the properties of reservoir fluids were added to the project, assuming the presence of water and oil in the model (typical brine properties with a density of $1040 \mathrm{~kg} / \mathrm{m}^{3}$ and oil with a density of approx. $820 \mathrm{~kg} / \mathrm{m}^{3}$ were assumed). Relative linear permeability was assumed with the critical saturation values of 0.1 for water and 0.32 for oil. In this work the case of immiscible fluids was considered where the molecular diffusion is equal to zero and main phenomenon occurring during fluid displacement is physical dispersion resulting from the complicated flow through the porous media $[4,6,8,16,21,28]$. The next stage was the creation of the socalled model work strategy (schedule) in which the operation of two wells located at the ends of the model was assumed, one of which was intended for water injection and the other for the fluid production. In this scenario, it is assumed that the rate of water injection into the model under reservoir conditions is equal to fluid production in these conditions. This allows to obtain stationary pressures in the model, which greatly simplifies the calculation and does not interfere with the results of the method used. In the discussed scenario, one time step was assumed at the level of 0.01 day and the simulation is performed iteratively up to 0.5 day.
The next stage of this work was the construction of a simulation case (Figure 2), i.e. a simulation model that will be launched in the Eclipse simulator via Petrel (and a script built in it). This option takes into account all the elements described above.

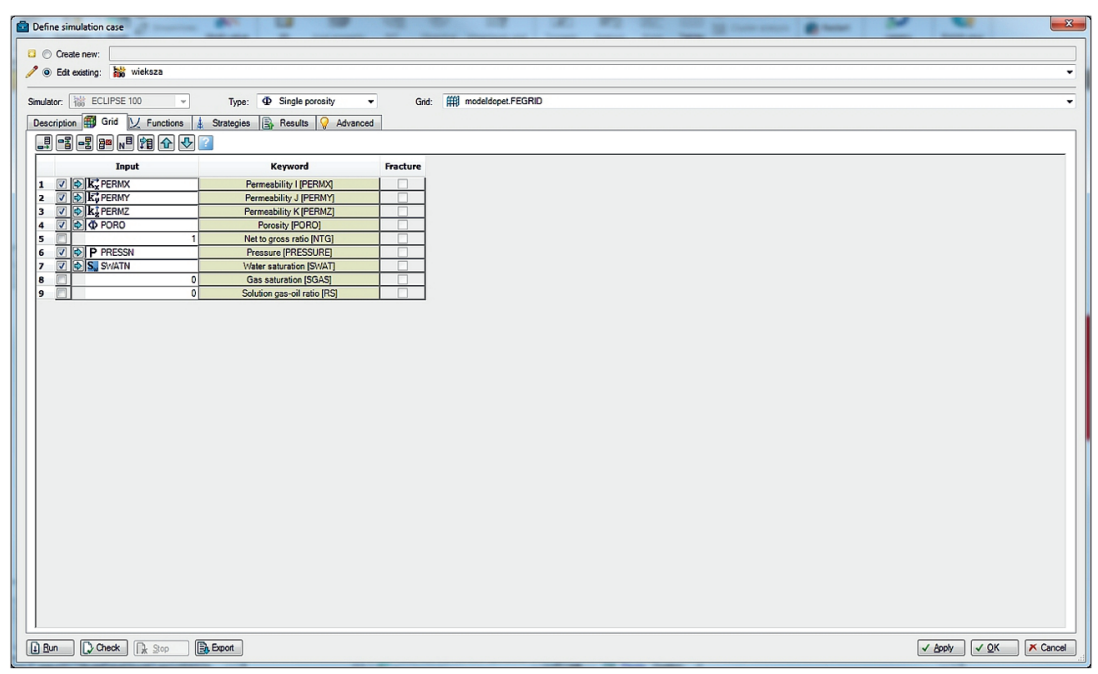

Fig. 2. Definition of the simulation case

After the simulation case was prepared, construction of the script was started, the main purpose of which was to implement the developed method of control of reservoir fluid mixing. The developed Workflow consists in calculating a single simulation step, exporting the required results from it (e.g. formation volumetric factors, viscosities, pressures or relative permeabilities), performing additional calculations and calculating new reservoir fluid saturation on the basis of these results. Then the calculated reservoir saturations and pressures (obtained at the end of the first step) are imported into the simulation case as input data and the next step of the simulation is performed. The following steps are performed analogously, i.e. each next step is based on the results and calculations from the previous step.

Since the method of control of the fluid mixing phenomenon proposed in previous works consists of a hybrid method of limiting the numerical dispersion and extending the calculation of fluid saturation with an additional dispersion module $[3,13,19,25]$, the script primarily deals with minimization of numerical dispersion. Minimization of numerical dispersion is achieved (in modified simulator) through an efficient combination of two methods: calculating the fluid mobility using multi-point upstream weighting and double discretization grid. In the case of the developed script, it was assumed that all calculations would be performed on the refine grid. Because we are considering a one-dimensional case, the number of blocks obtained after grid refinement should not be a problem for the simulator. On the other hand, the effect of minimization of numerical dispersion through the grid refinement will be analogous to the effect obtained with a double discretization grid. 
The block grid of the model was thickened 1000 times using the Grid refinemnet option provided in Petrel program (Figure 3).

The second method of limiting numerical dispersion by using multipoint weighting when calculating fluid mobility was implemented in the script using a calculator (property calculator) and initial values at the beginning of the script (Figure 4).

These fixed values concerned the size of the time step, the number of model blocks, coefficients needed for the use of three-point weighting and the model size. Before calculating the mobility, the required results are exported from the simulation and imported into the static model on which the calculations are made (Figure 5).

The presented figure (Figure 5) shows the iteration loop (For loop command) which executes subsequent time steps starts here in the script. The multi-point weighting for water mobility calculations is shown in Figure 6. As already mentioned before, these calculations are performed using the Property

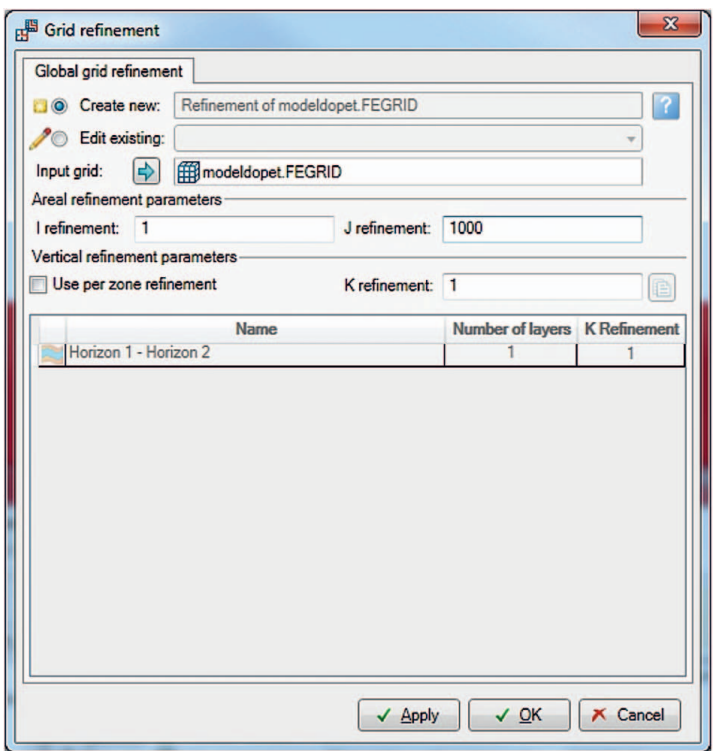

Fig. 3. Refinement of the model grid calculator tool, which allows one to perform operations on all blocks of the model simultaneously.

The last stage of the script under discussion concerns the calculation of new fluid saturations based on simulation results and calculations made earlier (Figure 7). These calculations have already taken into account an additional terms related to the phenomenon of physical dispersion (details like mathematical solutions concerning the proposed method of controlling the dispersion phenomenon have been presented in the author's previous works $[11,14,26])$. The size of physical dispersion can be set using two parameters, namely \$D and \$ALFA, initialized at the beginning of the script. Entering both non-zero parameters describes the linear dependence of physical dispersion on the flow velocity of the fluids (in this work, only \$D was entered as the testing model assumed stationary pressures and constant flow velocity of reservoir fluids). At the end of the script new saturation and pressure values from the previous step are exported to the simulation case and the iteration loop performs the next step.

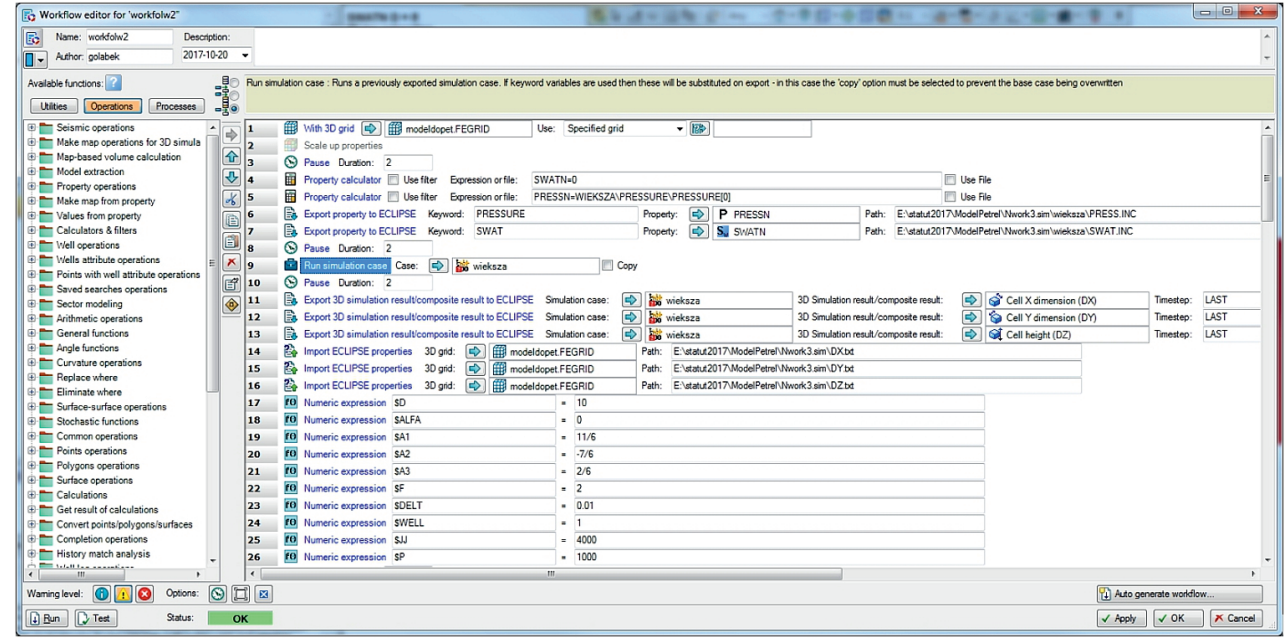

Fig. 4. Prepared script (Workflow) - initialization of data and parameters

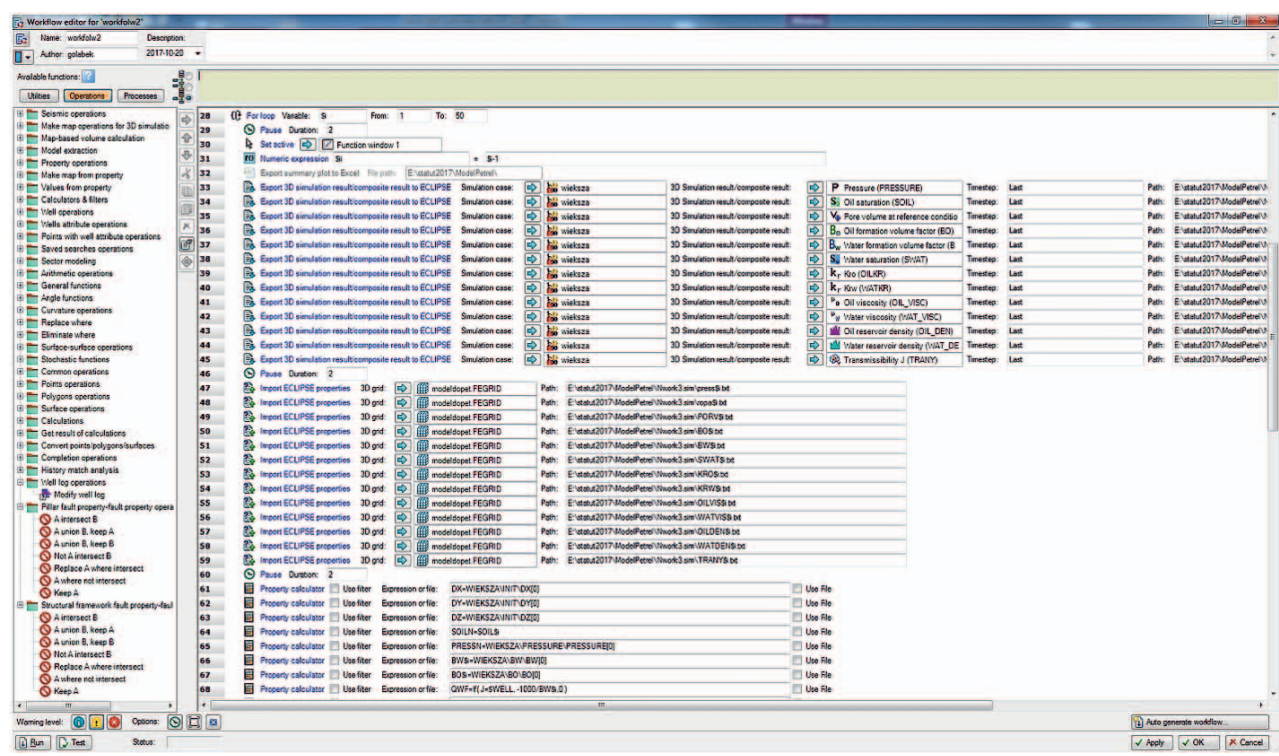

Fig. 5. Export/import of simulation results needed for calculation - start of the iteration loop 


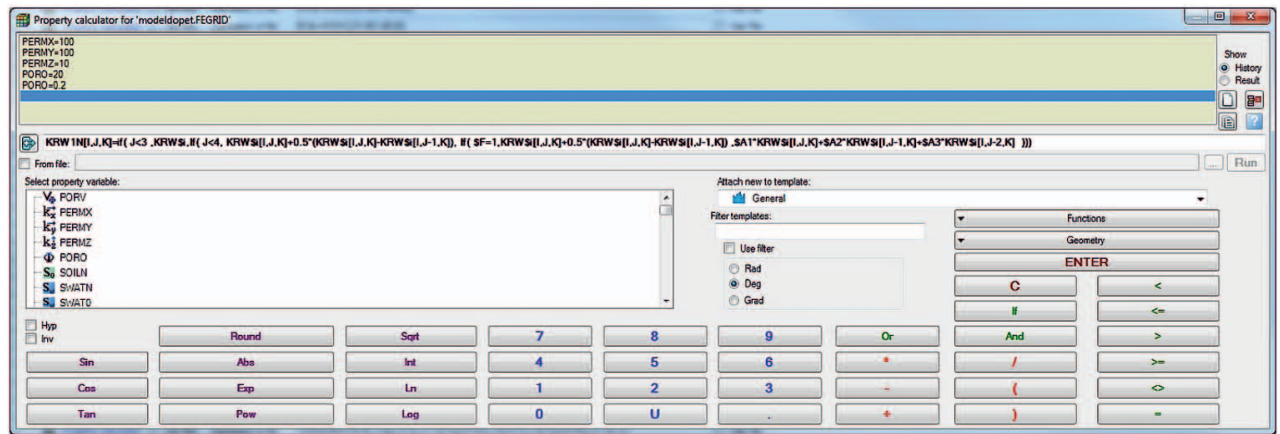

Fig. 6. The multi-point weighting for water mobility calculations

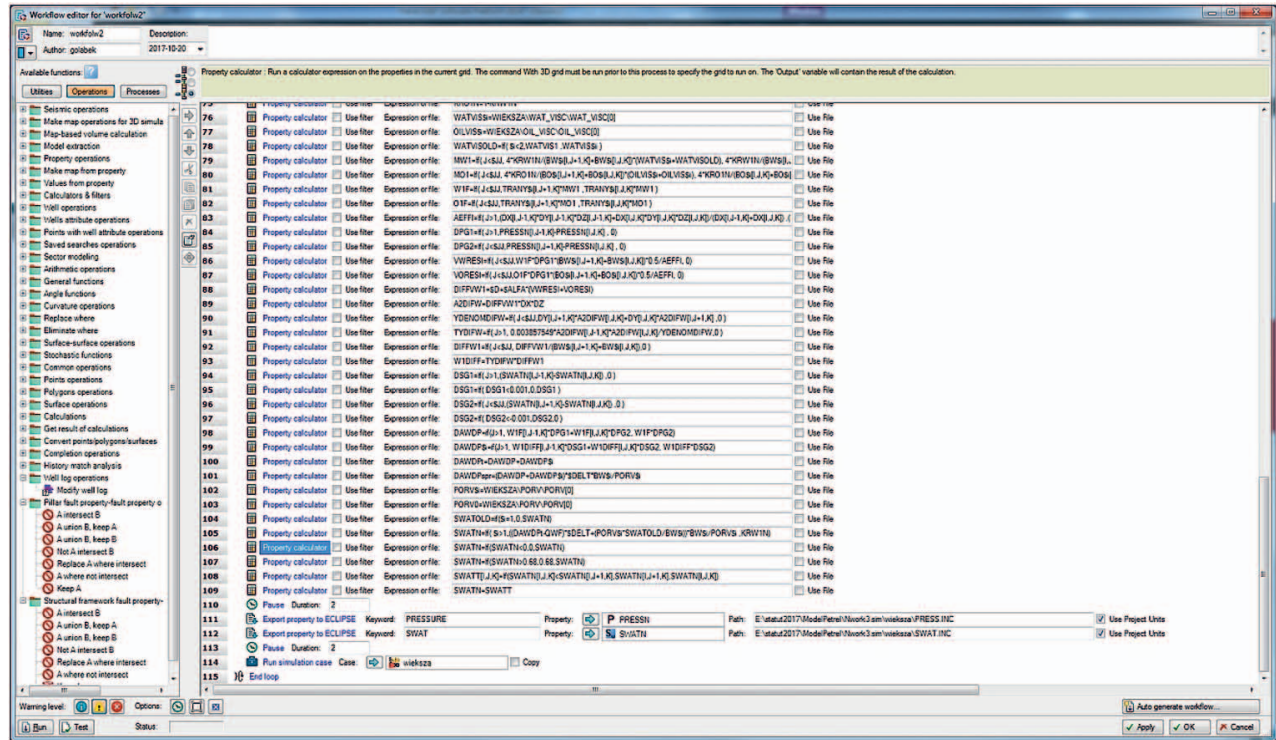

Fig. 7. Fluid saturation calculations taking into account physical dispersion

\section{Physical dispersion control}

The results of application of the script developed under the work allowing the control of physical dispersion are presented in Figures 8 and 9. These results are presented in the form of water saturation (injected medium) in particular blocks of the model after 50 iterative steps of the script. In order to better illustrate the results of the applied method, the models in these drawings have been reduced to the length of $30 \mathrm{~m}$.

Figure 8 refers to the minimization of numerical dispersion through the use of two-point and three-point weighting when calculating fluid mobility. This result also includes minimization of the numerical dispersion by using a highly refinement model grid (1000 times refinement). Using two-point weighting compared to the result without weighting provides a significant reduction of the size of the fluid mixing zone. On the other hand, the use of three-point weighting compared to two-point weighting is not so clear, but it still reduces the adverse phenomenon of numerical dispersion.

The second of the presented drawings (Figure 9) shows the size of the zone of mixing of the injected water with oil depending on the size of the control parameter D (physical

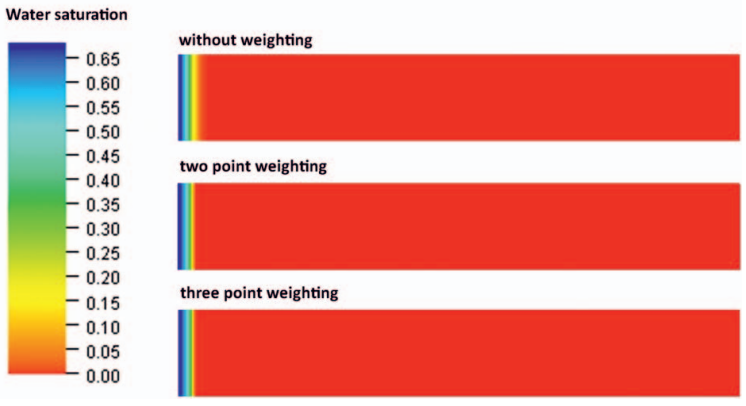

Fig. 8. The results of using weighting during calculation of fluid mobility

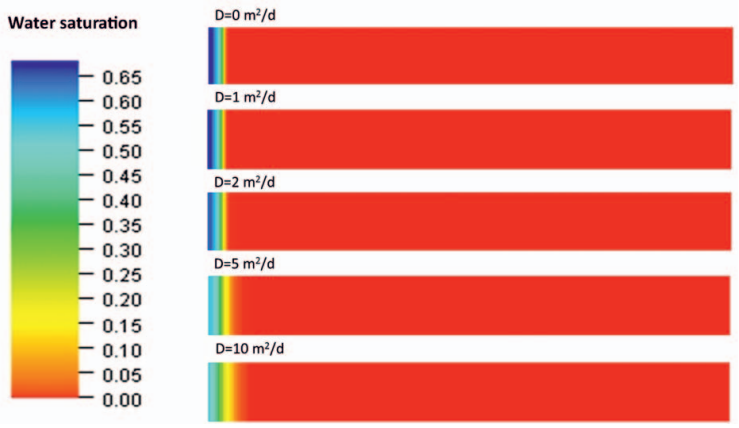

Fig. 9. The results of physical dispersion control 
dispersion). As can be seen in the discussed figure, the difference between $D=0 \mathrm{~m}^{2} / \mathrm{d}$, and $\mathrm{D}=1 \mathrm{~m}^{2} / \mathrm{d}$ is insignificant and the blurred effect caused by mixing of fluids is below
$1 \mathrm{~m}(0.79 \mathrm{~m}$ and $0.83 \mathrm{~m})$ in both cases. While the use of larger values of $\mathrm{D}$ parameter allows to increase this zone several times.

\section{Summary and conclusions}

The work deals with the issue of numerical modeling of physical dispersion phenomenon. This work uses the method proposed in the previous author's works of minimizing numerical dispersion (through multipoint weighting during calculations of fluid mobility and the use of a double discretization grid) and setting physical dispersion parameters (by including the dispersion terms in the equation of fluid flow between blocks). This method was implemented in Petrel program by constructing a script (Workflow) which performs calculations based on the results obtained in the Eclipse simulator.

The work also includes a one-dimensional static model, for which the implemented method of modeling of the physical dispersion phenomenon was tested.

\section{Conclusions}

1. Modeling of physical dispersion requires minimizing the numerical dispersion that occurs during simulation calculations, which can be achieved by changing the method of calculating fluids mobility and the concentration of the model grid for saturation calculations.
2. Use of the proposed petrel script (Workflow) make it possible to model the physical dispersion phenomenon based on the simulation results obtained from a commercial reservoir simulator, as demonstrated in the study for a onedimensional case.

Please cite as: Nafta-Gaz 2018, no. 10, pp. 732-738, DOI: 10.18668/NG.2018.10.04

Article contributed to the Editor 4.01.2018. Approved for publication 9.10.2018.

This paper was written on the basis of the statutory work entitled: Modelowanie zjawiska dyspersji fizycznej poprzez modyfikacje wyników standardowego symulatora złożowego (Modeling physical dispersion by modifying the results of a standard reservoir simulator) - the work of the Oil and Gas Institute - National Research Institute was commissioned by the Ministry of Science and Higher Education; order number: 120/KZ, archival number: DK-4100-159/17.

\section{Literature}

[1] Audigane P., Blunt M.J.: Dual mesh method in upscaling. SPE 79681, 2003.

[2] Azin R. et al.: Investigation of Underground Gas Storage in a Partially Depleted Gas Reservoir. SPE 113588-MS, 2008.

[3] Bijeljic B., Blunt M.J.: A Physically-Based Description of Dispersion in Porous Media. SPE-102869-MS, 2006.

[4] Coats K.H., Whitson C.H., Thomas L.K.: Modeling Conformance as Dispersion. SPE 90390-MS, 2009, pp. 33-47.

[5] Eclipse Black Oil and Compositional, v 2010.1 firmy GeoQuest Schlumberger.

[6] Fanchi J.R.: Multidimensional Numerical Dispersion. Society of Petroleum Engineers 1983, vol. 23, no. 1, pp. 143-151.

[7] Fanchi J.R., Harpole K.J., Bujnowski S.W.: BOAST: A threedimensional, three-phase black oil applied simulation tool (Version 1.1) Volume 1: Technical Description and FORTRAN Code. Bartlesville Energy Technology Center 1982.

[8] Gelhar L.W, Collins M.A.: General analysis of longitudinal dispersion in nonuniform flow. Water Resour. Res. 1971, vol. 7, no. 6, pp. 1511-1521.

[9] Gołąbek A., Miłek K., Szott W.: Symulacyjne modelowanie procesu konwersji złoża na PMG i regularnej jego pracy, z udziatem $\mathrm{CO}_{2}$ jako gazu buforowego. Czesść I-Konstrukcja i weryfikacja modelu, symulacja procesu wytwarzania buforu magazynu. Nafta-Gaz 2011, no. 3. pp. 153-162.
[10] Gołąbek A., Miłek K., Szott W.: Symulacyjne modelowanie procesu konwersji złoża na PMG i regularnej jego pracy, z udziatem $\mathrm{CO}_{2}$ jako gazu buforowego. Czesść II - Symulacyjne prognozy pracy magazynu. Nafta-Gaz 2011, no. 4, pp. 240-248.

[11] Gołąbek A., Szott W.: Modyfikacje symulatora złożowego dla potrzeb modelowania zjawisk mieszania się gazów. Nafta-Gaz 2015, no. 3, pp. 177-184.

[12] Gołąbek A., Szott W.: Numeryczne modelowania zjawiska dyspersji fizycznej-model rzeczywistej struktury. Nafta-Gaz 2017, no. 2, pp. 75-80, DOI: 10.18668/NG.2017.02.01.

[13] Gołąbek A., Szott W.: Symulacyjne modelowanie procesu konwersji złoża PMG i regularnej jego pracy z udziałem $\mathrm{CO}_{2}$ jako gazu buforowego. Praca statutowa Instytutu Nafty i Gazu - PIB, 2010.

[14] Gołąbek A., Szott W.: Trójwymiarowy symulator złożowy umożliwiajacy modelowanie mieszania się gazów. Praca statutowa Instytutu Nafty i Gazu - PIB, 2015.

[15] Kreft A., Zuber A.: On the Physical Meaning of the Dispersion Equation and its Solutions for Different Initial and Bonduary Conditions. Chemical Engineering Sciance 1978, vol. 33, pp. 1471-1480.

[16] Li D.: Comparative Simulation Study of water Flood. Technology Interface Journal 2010, vol. 10, no. 3, 7 p.

[17] Miłek K., Szott W., Gołąbek A.: Symulacyjne badanie procesów wypierania metanu rozpuszczonego $w$ wodach 
złożowych poprzez zatłaczanie gazów kwaśnych w ramach ich sekwestracji. Nafta-Gaz 2013, no. 2, pp. 112-122.

[18] Peaceman D.W.: Fundamentals of numerical reservoir simulation. Elsevier Scientific Publishing Company 1977.

[19] Perkins T.K., Johnston O.C.: A review of Diffusion and Dispersion in Porous Media. SPE Reprint Series, Miscible Displacement 1963, pp. 77-91.

[20] Redlich O., Kwong J.N.S.: On the Thermodynamics of Solutions. V. An Equation of state. Fugacities of Gaseous Solutions. Chem. Rev. 1949, vol. 44, no. 1, pp. 223-244.

[21] Reid, R.C., Prausnitz, J. M., Polling B.E.: The Properties of Gases and Liquids. McGraw-Hill, New York, USA 1987.

[22] Shrivastava V.K., Nghiem L.X., Okazawa T.: Modeling Physical in Miscible Displacement - Part 1: Theary and the Proposed Numerical Scheme. Journal of Canadian Petroleum Technology 2005, vol. 44, no. 5, pp. 25-33.

[23] Soave G.: Equalibrium Constants from a modified RedlichKwong equation of state. Chemical Engineering Science 1972, vol. 27, pp. 1197-1203.

[24] Szott W.: Zastosowanie symulacji komputerowych do modelowania pracy podziemnych magazynow gazu w Polsce. Nafta-Gaz 2010, nr 5, s. 339-344.
[25] Szott W. i in.: Modelowanie symulacyjne PMG Wierzchowice dla określenia charakterystyk pracy magazynu $i$ wspomagania jego zarzadzaniem w sezonie 2012/2013. Krosno December 2012 and earlier dokumentations concerning reservoir simulations of Wierzchowice USG for years 2004-2011.

[26] Szott W., Gołąbek A.: Symulacyjne modelowanie procesów mieszania się gazów w warunkach złożowych. Nafta-Gaz 2014, no. 3, pp. 151-161.

[27] Tood M.R., O’Dell P.M., Hirsaki G. J.: Methods for Increased Accuracy in Numerical Reservoir Simulators. SPE 3516, 1972.

[28] Vitousek S., Fringer O.: Physical vs. numerical dispersion in nonhydrostatic ocean modeling. Ocean Modelling 40 (2011) 72-86.

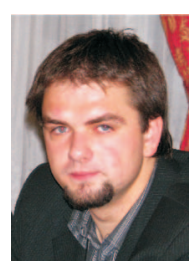

Andrzej GOŁĄBEK M.Sc. Eng. Junior Scientist

Department of Hydrocarbon Reservoir and UGS Simulation

Oil and Gas Institute - National Research Institute ul. Lubicz 25 A, 31-503 Kraków

E-mail: andrzej.golabek@inig.pl

\section{OFERTA}

\section{ZAKŁAD SYMULACJI ZŁÓŻ WĘGLOWODORÓW I PMG}

Zakres działania:

- $\quad$ sporządzanie ilościowych charakterystyk złóż naftowych (konstruowanie statycznych modeli złożowych);

- $\quad$ analizy geostatystyczne dla potrzeb projektowania modeli złóż naftowych, w tym PMG i wielofazowych obliczeń wolumetrycznych;

- konstruowanie dynamicznych symulacyjnych modeli złóż i ich kalibracja;

- wszechstronne badania symulacyjne dla potrzeb:

» weryfikacji zasobów płynów złożowych,

» wtórnych metod zwiększania wydobycia (zatłaczanie gazu lub wody, procesy WAG, procesy wypierania mieszającego, oddziaływanie chemiczne),

» optymalizacji rozwiercania i udostępniania złóż,

» prognozowania złożowych i hydraulicznych (w tym termalnych) charakterystyk odwiertów (w szczególności poziomych) dla celów optymalnego ich projektowania,

» sekwestracji $\mathrm{CO}_{2}$;

- $\quad$ projektowanie, realizacja i wdrażanie systemów baz danych dla potrzeb górnictwa naftowego.

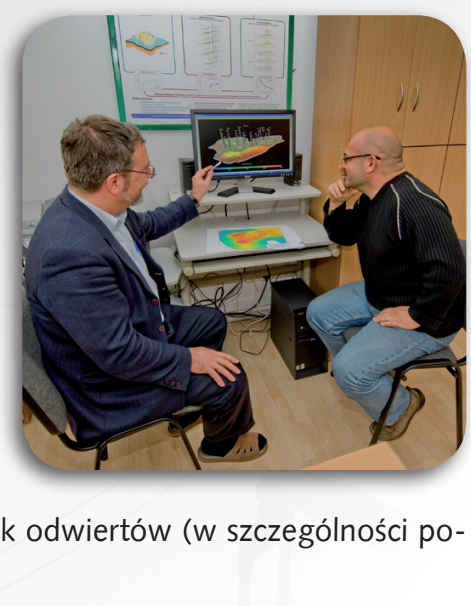

